\title{
Making writing practices visible and sustainable in the engineering curriculum: a practice architectures theory analysis \\ Rosalie Goldsmith ${ }^{1}$, Keith Willey ${ }^{2}$ \\ University of Technology Sydney ${ }^{1}$, University of Sydney ${ }^{2}$ \\ Rosalie.goldsmith@uts.edu.au
}

\begin{abstract}
Engineering practice requires engineers who have strong spoken and written communication skills, but the development of these skills, notably writing practices, is often invisible in the engineering curriculum, and rarely embedded. Decades of reviews of engineering education have identified the gap between the engineering curriculum and engineering practice, such as engineering graduates' level of writing skills being inadequate for the workplace. This paper draws on research from a qualitative study which investigates the perspectives of engineering educators about writing practices in the engineering curriculum, utilizing the theory of practice architectures as a theoretical and methodological lens. Using examples from the case studies, we explore some constraints of the development of writing practices in the engineering curriculum. We then focus on case studies where the development of writing practices is enabled within a subject, across a sequence of subjects and throughout an engineering degree program, and identify elements that contribute to these practices. Our findings suggest that the development of writing practices can be integrated into engineering studies, but certain pre-conditions are required.
\end{abstract}

Keywords: engineering writing, practice architectures theory, engineering curriculum

\section{INTRODUCTION \\ 1.1. Motivation for the paper}

Engineering practice requires engineers to create, innovate, collaborate, coordinate and communicate. As part of their everyday practice engineers need to reason, argue, explain, discuss, negotiate, recommend, justify and evaluate, both orally and in writing. However, there is a significant gap between the writing practices in the engineering curriculum and those of engineering practice, which has been identified in studies and reviews of engineering education, for example [1]; [20]; [24]; [27]; [28]; [29]; [32]; [36]; [39]. Several researchers note that employers are disappointed by engineering graduates' lack of 'business-specific writing' [20] and a lack of adaptability to the writing skills needed in the workplace [1]. According to accrediting bodies such as ABET, Engineers Australia (EA), and the Engineering Council (UK), and by the engineering faculties that teach engineering, the attainment of written and spoken communication skills in engineering students is an intended outcome of the engineering curriculum: 'Effective oral and written communication in professional and lay domains' [7, p.2]. Employers expect engineering graduates to be able to communicate clearly and professionally. 'The expected abilities for communicating clearly include... being concise; giving sufficient explanation; and giving clear, high-level overviews' [34 p.138].

Nevertheless, writing practices continue to be invisible in the engineering curriculum. While some engineering educators and writing instructors have worked tirelessly to help students develop their writing, the traces of this work are hard to detect over time, suggesting that the problem may lie more within the engineering curriculum than with engineering students.

\subsection{Literature review}

It is difficult to ascertain where writing practices are developed within the engineering curriculum, even with a close examination of subject outlines or by mapping graduate attributes. Such investigations can reveal where writing does or does not take place, but may not indicate how writing in the context of the subject is practised, nor the level of writing practice required. There may be excellent writing practices in one engineering subject but these may not be developed in subsequent subjects. For example, first year engineering students at two Australian universities are not required to do any writing except for notation for six 
of the eight subjects (University A) and for seven of the eight subjects (University B) [12], and this trend continues in later year subjects. If writing practices are introduced, they are usually located in one or two subjects that are seen to be the domain of 'soft skills' development (engineering management, engineering communication), rather than being seen as part of the technical knowledge of content areas [5]; [17]. This both isolates writing practices as not being part of 'real engineering' and limits the opportunities for their development. The continued existence of writing practices is not guaranteed, even in subjects where they have been embedded; changing circumstances (staffing, student numbers, budgetary constraints) can quickly cause them to be no longer practised, or to be downgraded to de-contextualised written artefacts.

Such an under-representation of writing either as process (practice) or as product (artefact) does not reflect what occurs in engineering practice. It suggests that those who enact the engineering curriculum do not see writing (whether in an instrumental function or as a vehicle for learning) as being an explicit element of the curriculum. The emphasis appears to be on the transmission of engineering science knowledge, as noted in several studies over the last few decades (e.g. [10]; [20]; [24]; [31]; [40]). Furthermore, it is unclear who is responsible for the development of writing practices, nor is it clear who among engineering educators feels confident to do so [11]; [22]; [29]; [36].

Both the lack of visibility of writing practices in the engineering curriculum and the uncertainty about whose role it is to develop the graduate attribute of communication highlight gaps in the research in the role of engineering educators in this regard. Much of the literature focuses on initiatives for engineering students to develop or improve their writing, often with assistance from an academic language and learning (ALL) instructor, within a subject or across an engineering program. Many of the strategies reported in the literature are optional adjunct subjects or resources [4]; [8]; [13]; [14]; [25] [28]; [31]; [36]; [37]; [41] (see also [29] for their comments on the number of publications on developing engineering students' writing). Literature on the perspectives of engineering educators about developing writing practices is less common and mainly examines the research writing practices of engineering educators and of their research students [6]; [9]; [21]; (see also [3]), or the writing of practising engineers [44] and of engineering students becoming novice engineers [2]; [45].

Studies which have examined engineering educators' perspectives of writing in the curriculum include Jenkins, Jordan and Weiland [16], who surveyed engineering faculty staff about their beliefs and practices of engineering writing in the context of the role of writing in postgraduate engineering subjects in US universities. Zhu [46] compared business and engineering faculty members' views of student writing in their respective disciplines in one US university. Zhu's [46] primary concern, like that of Jenkins et al. [16], is how to support ESL students in their disciplinary writing. Both studies have a similar context: they are set in American universities, where there are specific programs of writing instruction for all students, unlike Australian universities. An Australian context for the engineering faculty perspectives of writing is provided by Howard and colleagues [15], who examined engineering educators' views about writing and online tools to support the development of engineering students' communication capabilities. All three studies found that writing is seen as important for engineering students, but how students develop their writing practices is not the typical concern of engineering faculty.

The conception of engineering as being solely or mainly about cutting edge technology and technical fixes occurs frequently in popular culture, and in promotional materials for engineering subjects at university: images of robots and rockets tend to feature heavily. Engineers do not come across as having excellent coordination and communication skills, nor do these images represent 'a creative activity based on science, mathematics and technical knowledge applied with art...' [7, p.8]. In fact, there is a tension between practising engineers and engineering educators about the focus on engineering science in the curriculum and the lack of emphasis on developing professional attributes, as noted in [20 p.68].

\subsection{Problem definition}

It can be seen from the review of the literature that there are significant gaps in our understanding of how writing practices are perceived and developed in the 
engineering curriculum. Thus the purpose of this study is to investigate what makes writing practices invisible in the curriculum; to problematise the idea of the 'nonwriting engineering curriculum'; to see how prevailing practices in the engineering curriculum constrain rather than enable writing practices. By exploring this problem, writing practices can become visible and a language is provided with which to discuss review the issues. Without this visibility and this language, writing practices in the engineering curriculum will continue to struggle to be seen as an integral practice of learning to become a professional engineer.

\section{METHOD AND METHODOLOGIES}

The current study examines some constraints and enablers of the development of writing practices in the engineering curriculum. It has an Australian focus, but as is shown in the literature, similar challenges occur around writing practices in other engineering education contexts (e.g. [1]; [8]; [23]; [30]; [39]). A case study methodology was used in combination with practice architectures theory to analyse how writing is practised in engineering subjects (also referred to as courses or units in Australian universities).

The study uses practice architectures theory as both a theoretical perspective and a methodological lens. Practice architectures theory (PAT) (e.g. [18]) has evolved from Schatzki's practice theory (e.g. [35]), where the focus is on the site of practice, how the practice is conducted, its temporal and physical location, and the arrangements that hold it in place. PAT can allow investigators to see not only what is happening in a practice, but how this has come to be and why certain practices become 'the way we do things around here'. In keeping with Schatzki's understanding of the localised nature of practices, PAT is used to analyse a site of practice; a site of practice is 'that realm or set of phenomena of which it is a part' (Schatzki, 2003 [26 p. 9]). In this study, sites of practice are the engineering subjects taught by the participants. In addition to providing a lens to analyse practices and what lies behind them, PAT also provides the language to discuss the complex interplay of forces that create conditions in which certain types of learning are constrained and other types of learning are enabled. It does this by identifying three different kinds of arrangements that exist simultaneously in a site of practice, and which hold those practices in place: cultural-discursive arrangements, material-economic arrangements and social-political arrangements. Cultural-discursive arrangements are resources that prefigure what can be said and thought about a practice (the sayings); material-economic arrangements (the doings) include aspects of the physical environment, financial resources, and divisions of labour that shape the doings of a practice; social-political arrangements incorporate organisational functions, rules and roles that shape the relationships (relatings) amongst participants and non-human objects in a practice [19]. It is important to note that the arrangements should not be considered or analysed separately; they interact with one another to prefigure (but not predetermine) the happenings of a site of practice. For example, what is thought and said about writing in the engineering curriculum (cultural-discursive arrangements) interacts with how writing is developed and assessed in engineering subjects (material-economic arrangements), and both of these practice architectures interact with how engineering educators relate to their students as practitioners of engineering writing (socialpolitical arrangements). Working in concert, these arrangements thus both enable certain teaching and learning practices of writing in engineering, and constrain others.

Nine engineering educators who coordinate an engineering subject in undergraduate or postgraduate degree programs in Australian universities were recruited from five institutions in three states; all the participants teach technical subjects from a wide range of engineering disciplines. The participants were asked to provide relevant documents such as subject outlines, support documents and samples of student assignments if available. Published writing by the participants, available in the public domain, was also collected. The documents were analysed to identify practices of teaching, learning and assessment, and the participants were then interviewed using semi-structured questions to investigate how they view their students' writing practices, their own writing practices as engineers, and the writing practices of the engineering curriculum. The interviews were transcribed and analysed to identify emergent themes using Concordance software [42] which identifies frequency of occurrence of words.

CEEA18; Paper 019

University of British Columbia; June 3-6, $2018 \quad-3$ of $9-$ 
These themes were then re-analysed to identify elements of practices. Three participants agreed to being observed while teaching; the first author attended their lectures or tutorials and took notes, which were later transcribed. As per ethical requirements, all participants have been de-identified and are referred to by pseudonyms; their institutions are referred to by letters.

\section{RESULTS AND DISCUSSION}

In this paper we first discuss practices that do not support the development of writing practices within engineering subjects, with examples taken from sites of practice. We then present examples where writing practices are supported and developed not only within an engineering subject but across several subjects, and throughout an engineering discipline. We discuss the practice architectures that hold these practices in place, and consider the conditions that allow these practices to flourish. Our findings suggest that the development of writing practices can be integrated into engineering studies, but certain pre-conditions are required.

\subsection{Unsupported writing practices}

An unsupported practice of writing is where the practice architectures and elements of practice provide no space for writing practices. Instead all the space is taken up with practices that support the teaching and learning of technical knowledge. Shove, Pantzar and Watson [38] claim that practices are in competition for time and space, and argue that 'practitioner-time [is]... a necessarily limited, inherently finite resource, the allocation of which reflects the relative dominance of some practices over others...' (p.127). This competition is enacted in the sites of practice in this study and is evident in the sayings of the participants when they talk about how little time there is to cover all the topics in the subject and the cost of marking written assignments compared to marking quizzes. The majority of the case studies showed evidence of unsupported or fragmented support for writing practices. Table 1 summarises some of the unsupported writing practices.

Table 1: Unsupported writing practices

CEEA18; Paper 019

University of British Columbia; June 3-6, 2018
A lack of meta-language with which to talk about writing practices; unhelpful or non-existent feedback on written assignments (cultural-discursive)

No opportunities for students to practise writing during classes (material-economic)

No time allocated to developing writing practices in class or for homework (material-economic)

Minimal assessment weighting given to the quality of writing (material-economic)

Little/no observable agency on the part of the engineering educator to enact elements of practice that would enable students to practise writing (socialpolitical)

No visible links between one subject and the next, or between the writing practices developed within one subject and what might be practised or expected in subsequent subjects (social-political)

The following paragraphs discuss unsupported writing practices in two of the case studies, those of Felicity and Garth. Felicity (from University C) teaches a technical third year electrical engineering subject; the cohort size is approximately 110 . The subject is 'a core unit [subject] that develops fundamental electrical circuit concepts essential for an electrical engineer' (Felicity subject outline 2014 p.1). The assessment of the subject consists of: in class quizzes (10\%); a problem-solving task (group assignment) 40\%; laboratory/practical experiments (10\%) and a final exam $(40 \%)$.

There are five learning outcomes listed in Felicity's subject outline; not surprisingly in a later year technical subject the emphasis is on the acquisition of technical knowledge, but learning outcomes 3 and 4 are worded as though they would require students to write discursively.

3. Identify fundamentals of power system economics, generation costs, tariffs, market rules and performance 4. Explain principles of single and three phase transformers operation and performance (winding, testing, losses and efficiency) (Felicity subject outline p.2).

In addition, the description of the final examination for this subject implies that students would be expected to produce answers involving extended writing: 'The final exam [written] of two hours in length will be aimed at evaluating problem formulation, general knowledge 
and the relationships of fundamental knowledge to the systems studied' (Felicity subject outline p.3). However, there is no mention in the subject outline, nor in the interview, nor in the assessment documents, of writing, and no examples of it being practised - neither in the practice architectures nor in the practices. It appears that students will be expected to acquire learning outcomes that assume writing as negotiated meaning, and will be tested on this, at least implicitly, but without the opportunity to practise this kind of writing. The writing of numbers (equations, formulae and calculations) is present, but this is not seen as writing by Felicity and may not be seen as writing by students, as demonstrated by what she says:

...rather than writing a report or providing some document they need to attempt different examples, questions during tutorial sessions...So - not for this case, for this unit [subject] - they do not need to write lots of reports... (Felicity interview)

The practice architectures - the cultural-discursive, material-economic and social political arrangements and the elements of the practice -the sayings, doings and relatings - support the learning of technical knowledge. This is enacted by language, activities and the value put on technical knowledge. At the same time, the practice architectures and elements of practices within Felicity's site constrain the practice of writing. In this site of practice, writing other than notation is invisible, and perhaps does not occur. The practice of encouraging students to explain technical concepts in words as well as in numbers does not take place. In other words, the emphasis on the technical knowledge of the discipline in Felicity's site does not allow writing to be thought of as part of learning electrical circuit concepts; the cultural-discursive arrangements are 'constraining what it is relevant to say' [19, p.32] or to think about the practice of writing in electrical engineering. Felicity's sayings focus on the technical knowledge that the students are acquiring, even when she is specifically asked about their writing practices; the examples she gives are figures and screenshots of results, not words. The assignments are projects with reports but the emphasis is on accuracy of calculations and solutions, not on explanations or evaluations.

Another example of unsupported writing practices can be seen in Garth's case study (University C), who teaches a third year civil engineering subject (cohort size about 300) where the 'problem based learning projects' (Garth subject outline 2014 p.3) are in fact questions that require mathematical equations. Garth acknowledges that he changed the focus of the student project to emphasise solving mathematical problems because:

...we have too many things that we want to teach and we only have 13 weeks. So we...use tutorial times...to teach something. So I thought that is the best way to utilise the time but by doing that there's no practice actually for a student to improve their writing skill (Garth, interview).

Garth's comment here epitomises the practice architectures around writing practices in the engineering curriculum, and the view espoused by many engineering educators: writing practices are described as important until they compete for scarce resources and for status- the material-economic arrangements and the social-political arrangements in the engineering curriculum of space and relevance within the curriculum, of time on task, of teaching time, of the time taken to mark assessment tasks, and then they become less important. Because of these pressures, it becomes unthinkable and undoable to have writing practices take up space in the teaching activities of his subject, 'because there are so many other important things that we want to include and teach' (Garth interview). There is too little time in the class or the semester, or it is not someone's job to teach writing, or writing is important but not quite as important as the technical knowledge taught by the subject coordinator.

We argue that in such circumstances, writing is not a practice but an activity. It is difficult to find evidence of opportunities for students to practise writing in tutorials or laboratory sessions, in contrast to the time allocated to practising calculations and doing worked examples of problems. Unlike the development of students' technical or technical knowledge, writing is mostly not practised formatively. However, it is assessed summatively in the reports that students are asked to produce, indicating that the view of 'the writeup', as opposed to the view of writing as a practice, is alive and well.

\subsection{Supported writing practices}

CEEA18; Paper 019

University of British Columbia; June 3-6, 2018 
The practice architectures of the case studies where writing as a practice is visible and supported beyond the local site are formed by a complex interaction of pedagogical practices, collegial practices, and agency of the participants. These practice architectures are summarized in Table 2. A few of the case studies had fragments of these arrangements, but not sufficiently to support writing practices within their site of practice.

Table 2: supported writing practices in the engineering curriculum

Writing spoken of and thought of as a practice; written communication a specific learning outcome of the subject (cultural-discursive arrangements)

Writing practised in class or online; writing given formative or summative feedback; writing modelled and/or exemplars provided; writing given specific weighting in assessment tasks (material-economic arrangements)

Writing part of the subject assessment; writing practices part of the identity of the professional engineer; writing practices linked to other subjects in the curriculum (social-political arrangements)

The three case studies which evidence supported writing practices either within or beyond their site of practice are: Bernice (university A); Harry (University D) and Damien (university B). The pedagogical practices include: participants talking about writing practices as being key to learning (sayings); their students enacting writing practices in class time or for assignments (doings); providing formative feedback to their students (doings) and demonstrating knowledge of writing practices in subjects taught by their colleagues (relatings). The collegial practices of the participants involve working with engineering colleagues to extend the writing practices beyond their sites, and allowing the practice of writing to be seen as developmental.

While two of the case studies supported writing practices within their site of practice (Bernice) or across sequential subjects (Harry), only one case study (Damien) provides an example of supported practices that extend throughout the engineering degree program in his school. Damien is a professor in the school of $\mathrm{X}$ engineering at University $\mathrm{B}$ and has been an engineering educator for some years, with prior experience in industry. This school belongs to a discipline of engineering that has a common curriculum shared by several Australian universities for years 3 and 4 of the Bachelor degree. He teaches a second year subject in $\mathrm{X}$ engineering.The cohort size is approximately 80 students. The assessment tasks for this subject are: 2 numerical reports worth $20 \%$ and $5 \%$, two field reports worth $15 \%$ and $30 \%$ each and a final examination worth 30\% (Damien subject outline 2014, p.7). The first field report is preliminary, to provide students with formative feedback. The second report is based on the first one.

There are four learning outcomes of Damien's subject; the fourth one states: "students are expected to be able to...prepare a technical report that presents the results of a study on a $[\mathrm{X}]$ project that is consistent with the requirements and standards of the School of $[\mathrm{X}]$ Engineering and relevant professional society" (Damien's subject outline 2014, p.3). The practice architectures and practices of Damien's site interact to provide extensive support for writing practices within and beyond this site. Most striking is the report writing guide, used by all the Australian engineering faculties sharing the common curriculum of $\mathrm{X}$ engineering discipline, and to which Damien has made significant contributions. It is a substantial document (84 pages) which provides extensive information about the field-specific requirements of engineering reports in terms of content, format, language and presentation, with exemplars, and was in its ninth edition at the time of this study. The existence of the report writing guide prefigures the perception by students and staff that writing is a practice, and that writing reports is an integral practice in the discipline of $\mathrm{X}$ engineering. The practice of revising the report writing guide demonstrates that writing practices are developmental and emergent, not fixed [33]. None of the other case studies in this research has an artefact like the report writing guide; at best there are learning guides or assignment guidelines which are specific to the subject and which would probably fall into disuse if the subject coordinator moved on to another subject or to another institution.

The cultural-discursive arrangements of Damien's site support his sayings about the relevance of writing practices to the study of $\mathrm{X}$ engineering. The subject outline includes assessment criteria for the assignments which specifically mention "Interpretation of 
information and calculations" and "Discussion and demonstration of further research" (Damien subject outline 2014, p.9). The practices include a lecture given by to all first year students enrolled in the school of $\mathrm{X}$ engineering and the report writing guide.

Two of the assessment items in Damien's subject require students to write reports that require them to discuss and interpret observations or results. Report writing is practised and scaffolded in Damien's subject and is developed through the major in which his subject is situated. Students receive explicit information about what is required in the writing of the report (with exemplars in the guide) and formative feedback. They also have the opportunity to practise their writing, both with the preliminary report: "The idea of the preliminary report is for the students to have two turns at writing the report" (Damien interview) and through an open-access online report writing site with selfpaced activities which features an engineering field report (Learning Centre University of Sydney 2012).

Damien refers to the 'cycle' of report writing that the students experience as they progress through their degree, and demonstrates his awareness of the developmental nature of writing practices, as the following comment illustrates:

Even introducing the first year, by the time they get to the fourth year it doesn't necessarily mean they can write good reports (Damien, interview).

The social-political arrangements and relatings in Damien's site of practice are notable - both Damien's leadership and the presence of the common curriculum within $\mathrm{X}$ engineering schools in different universities are unusual in the case studies, and powerful in the way that they hold the practices of report writing in place.

\section{CONCLUSION}

In conclusion, the analysis of Damien's case study using the lens of practice architectures theory shows that writing practices can be made visible if and when they are talked about, acted on and valued as part of the learning of engineering knowledge: the sayings, doings and relatings which are held in place by certain practice architectures. These include cultural-discursive arrangements which refer to writing as a developmental practice, material-economic arrangements such as faculty policies which state that written and spoken communication should be present in a proportion of

CEEA18; Paper 019

University of British Columbia; June 3- 6, 2018

-7 of $9-$ engineering subjects in each year of the degree, and social-political arrangements which establish links between subjects so that writing practices in one subject can be built on in subsequent subjects. For this to take place, as in Damien's site of practice, the influence of more than the faculty seems to be required - the socialpolitical and material-economic arrangements of Damien's educational leadership, the common curriculum in the field of $\mathrm{X}$ engineering and of the membership of the National $X$ engineering association could well be critical in holding the development of writing practices in place. This could be a rich vein for further research.

\section{ACKNOWLEDGEMENTS}

The authors wish to thank the participants who volunteered to be involved in this study. This research is supported by an Australian Government Research Training Program Scholarship.

\section{REFERENCES}

1. Appleby Y., Roberts S., Barnes L., Qualter P., Tariq V. Who wants to be able to do references properly and be unemployed? STEM student writing and employer needs. Journal of Learning Development in Higher Education. 2012. Special Edition, November 2012.

2. Artemeva N. Stories of becoming: A Study of novice engineers learning genres of their profession. In: C. Bazerman $\mathrm{AB}, \& \mathrm{D}$. Figueiredo editors. Genre in $a$ Changing World. Colorado: The WAC Clearinghouse; 2009.

3. Blakeslee A.M. Activity, context, interaction and authority: Learning to write scientific papers in situ. Journal of Business and Technical Communication, vol 11, no. 2, 125-69, 1997.

4. Carter M., Ferzli M., Wiebe E. Writing to learn by learning to write in the disciplines. Journal of Business and Technical Communication. Vol.21, 2007.

5. Colman, B., \& Willmot, P. How soft are 'soft skills' in the engineering profession? 44th SEFI Conference, Tampere, Finland, 2016.

6. Curry, M.J. Graphics and invention in engineers' writing for publication. In M.J. Curry \& D.I. Hanauer, (Eds), Language, literacy and learning in STEM education. Amsterdam: John Benjamins; 2014, pp. 87-106. 
7. Engineers Australia. Stage 1 competency standard for professional engineers 2013. https://www.engineersaustralia.org.au/sites/default/files /shado/Education/Program\%20Accreditation/130607_st age_1_pe_2013_approved.pdf.

8. Fischer, A. 'Hidden features' and 'overt instruction' in academic literacy practices: A case study in engineering. in T. Lillis, K. Harrington, M.R. Lea \& S. Mitchell (Eds.), Working with academic literacies. WAC Clearinghouse, Colorado, 2015. Retrieved from https://wac.colostate.edu/.

9. Gimenez, J.. Writing as social practice in engineering: Views from a cross-disciplinary study. In In M.J. Curry \& D.I. Hanauer (Eds.), Language, literacy and learning in STEM education. Amsterdam, John Benjamins. pp.87106, 2014.

10. Goldberg, D. The Big Beacon Manifesto, 2011. http://bigbeacon.org/big-beacon-manifesto.pdf

11. Goldsmith, R., \& Willey, K. "It's not my job to teach writing": Activity theory analysis of [invisible] writing practices in the engineering curriculum. Journal of Academic Language \& Learning, vol. 10, no.1, pp. A118-A129, 2016.

12. Goldsmith, R., Willey, K. \& Boud, D.. How can writing develop students' deep approaches to learning in the engineering curriculum? Proceedings of the 2012 AAEE Conference, Melbourne, Victoria, 2012.

13. Herrington, A.J., "Writing in Academic Settings: A study of the contexts for writing in two college chemical engineering subjects", Research in the Teaching of English, vol. 19, no.4, pp. 331-361, 1985.

14. Hilgers, T.L., Hussey, E. \& Stitt-Bergh, M., “'As you're writing, you have these epiphanies': What college students say about writing and learning in their majors", Written Communication, vol. 16, pp. 317-353, 1999.

15. Howard, S., Khosronejad, K. \& Calvo, R., Exploring Engineering instructors' views about writing and online tools to support communication in Engineering, European Journal of Engineering Education, 2016. \{DOI: 10.1080/03043797.2016.1228612\}.

16. Jenkins, S., Jordan, M.K. \& Weiland, P. O. The role of writing in graduate engineering education: a survey of faculty beliefs and practices, English for Specific Purposes, 12, 51-67, 1993.

17. Johnston, S., \& McGregor, H. Recognising and supporting a scholarship of practice: Soft skills are hard! Proceedings of the $15^{\text {th }}$ AAEE Conference, Toowoomba, Australia, 2004.

18. Kemmis, S. \& Mutton, R. Education for sustainability (EfS): practice and practice architectures. Environmental Education Research, vol.18, no.2, pp. 187-207, 2012.

CEEA18; Paper 019

University of British Columbia; June 3-6, 2018
19. Kemmis, S., Wilkinson, J., Edwards-Groves, C., Hardy, I., Grootenboer, P. \& Bristol, L. Changing Practices, Changing Education. Singapore: Springer, 2014.

20. King, R., Engineers for the Future: addressing the supply and quality of Australian graduates for the 21st Century, ALTC, 2008. http://www.olt.gov.au

21. Koutsantoni D. Developing Academic Literacies: Understanding Disciplinary Communities' Culture and Rhetoric. Bern, Switzerland, Peter Lang, 2007.

22. Kranov, A. A. 'It's not my job to teach them how to write': Facilitating the disciplinary rhetorical socialization of international ESL graduate assistants in the sciences and engineering. ASEE 2009 Annual Conference \& Exposition, Austin, Texas, 2009.

23. Leydens, Jon A.. Novice and insider perspectives on academic and workplace writing: Towards a continuum of rhetorical awareness, IEEE Transactions on Professional Communication, vol.51, no.3, September, 2008.

24. Lloyd, B., Rice M., Ferguson, C., Palmer, S. Engineering the Future: Preparing professional engineers for the 21st century. Brighton East, Victoria, Association of Professional Engineers, Scientists and Managers, Australia, 2001.

25. Lord, S.M. Integrating effective 'writing to communicate' experiences in engineering subjects: Guidelines and examples. International Journal of Engineering Education, vol. 25, no.1, pp. 196-204. 2009.

26. Mahon K., Kemmis S., Francisco S. \& Lloyd-Zantiotis A. Introduction: Practice Theory and the Theory of Practice Architectures. In: K. Mahon, S. Francisco \& S. Kemmis (Eds.), Exploring education and professional practice: Through the lens of practice architectures. Singapore: Springer, p. 1-30, 2017.

27. Male, S.A., Bush, M.B., \& Chapman, E.S. "An Australian study of generic competencies required by engineers", European Journal of Engineering Education, vol. 36, no.2. 2011

28. Mort, P., \& Drury, H. Supporting student academic literacy in the disciplines using genre-based online pedagogy. Journal of Academic Language and Learning, vol.6, no.3, pp.A1-A15, 2012.

29. Mort P., Drury H., Calvo R., Skinner I., McEwan A., \& Levy D. An online writing centre for engineering students. Proceedings of the 8th International CDIO Conference; 1-4 July, Queensland University of Technology, Brisbane, 2012.

30. Paretti, M. \& McNair, L.. Analyzing the intersections of institutional and dissubject identities in engineering work at the local level, Engineering Studies, vol.4, no.1, pp.55-78, 2012. \{DOI:

$10.1080 / 19378629.2011 .652120\}$. 
31. Pawley A. Universalized narratives. Journal of Engineering Education.vol. 98, no.4, pp.309-19, 2009.

32. Pflueger, R., Weissbach, R., \& Gallagher, S. Strengthening technical writing knowledge transfer through targeted study in a first-year composition subject. Proceedings of the Research in Engineering Education Symposium, Dublin, 2015.

33. Rooney D., Boud D., Reich A., Fitzgerald T., Willey K., Gardner A. Using practice theory to investigate professional engineers' workplace learning. Proceedings of the IEEE Frontiers in Education Conference 03-06 October, Seattle, USA, 2012.

34. Ruff, S., \& Carter, M.. Characterizing employers' expectations of the communication abilities of new engineering graduates. Journal on Excellence in College Teaching, vol.26, no.4, pp.125-147, 2015.

35. Schatzki, T. A Primer on practices. In J. Higgs, R. Barnett, S. Billett, M. Hutchings \& F. Trede (Eds.), Practice-based education. Rotterdam: Sense Publishers, 2012.

36. Shapiro, Ann, 1991. WAC and Engineering, or Why Engineers Can't Write, 42nd Annual Conference on College Composition and Communication, Boston, MA, March 21-23, 1991.

37. Skinner I., Mort, P., Calvo, R., Drury, H. \& Molina, M.G.. Some do, some don't: student use of online writing resources Proceedings of the 2012 AAEE Conference, Melbourne, Victoria, 2012.

38. Shove, E., Pantzar, M., \& Watson, M.. The Dynamics of Social Practice: Everyday life and how it changes, SAGE Publications Ltd, London, 2012.

39. Trevelyan, J., Engineering education requires a better model of engineering practice, Proceedings of the Research in Engineering Education Symposium, Palm Cove, Qld, 2009.

40. Trevelyan, J. Mind the gaps: Engineering education and practice, Proceedings of the 2010 AaEe Conference, UTS, Sydney NSW, 2010.

41. Walker, M. Engineering Identities. British Journal of Sociology of Education, vol. 22, no.1, pp.75-89, 2001. \{doi: 10.1080/01425690020030792\}.

42. Watt, R. Concordance. 2011. Retrieved from http://www.concordancesoftware.co.uk/

43. Wheeler, E., \& McDonald, R.L.. Writing in engineering subjects. Journal of Engineering Education, vol.89, no.4, pp.481-486, 2000

44. Winsor DA. Engineering writing/writing engineering. College Composition and Communication, vol.41, no.1, pp.58-70, 1990.

45. Winsor, D.A. Writing like an engineer: A rhetorical education. Mahwah, NJ: Lawrence Erlbaum Associates Inc. 1996

CEEA18; Paper 019

University of British Columbia; June 3-6, $2018 \quad-9$ of 9 -
46. Zhu, W. Faculty views on the importance of writing, the nature of academic writing, and teaching and responding to writing in the disciplines. Journal of Second Language Writing, vol.13, pp.29-48, 2004. 